Climate Politics as Investment 
Simon Wolf

\section{Climate Politics \\ as Investment}

From Reducing Emissions to Building Low-carbon Economies

Springer VS 


\section{Simon Wolf \\ Berlin, Germany}

Dissertation an der Universität Kassel, Fachbereich 5: Gesellschaftswissenschaften, unter dem Titel: „Climate politics as investment. A discourse theoretical analysis of how climate change turned into an economic challenge“, Disputation am 13. Juni 2012.

ISBN 978-3-658-02405-5

ISBN 978-3-658-02406-2 (eBook)

DOI $10.1007 / 978-3-658-02406-2$

The Deutsche Nationalbibliothek lists this publication in the Deutsche Nationalbibliografie; detailed bibliographic data are available in the Internet at http://dnb.d-nb.de.

Library of Congress Control Number: 2013938485

Springer VS

(C) Springer Fachmedien Wiesbaden 2013

This work is subject to copyright. All rights are reserved by the Publisher, whether the whole or part of the material is concerned, specifically the rights of translation, reprinting, reuse of illustrations, recitation, broadcasting, reproduction on microfilms or in any other physical way, and transmission or information storage and retrieval, electronic adaptation, computer software, or by similar or dissimilar methodology now known or hereafter developed. Exempted from this legal reservation are brief excerpts in connection with reviews or scholarly analysis or material supplied specifically for the purpose of being entered and executed on a computer system, for exclusive use by the purchaser of the work. Duplication of this publication or parts thereof is permitted only under the provisions of the Copyright Law of the Publisher's location, in its current version, and permission for use must always be obtained from Springer. Permissions for use may be obtained through RightsLink at the Copyright Clearance Center. Violations are liable to prosecution under the respective Copyright Law. The use of general descriptive names, registered names, trademarks, service marks, etc. in this publication does not imply, even in the absence of a specific statement, that such names are exempt from the relevant protective laws and regulations and therefore free for general use. While the advice and information in this book are believed to be true and accurate at the date of publication, neither the authors nor the editors nor the publisher can accept any legal responsibility for any errors or omissions that may be made. The publisher makes no warranty, express or implied, with respect to the material contained herein.

Printed on acid-free paper

Springer VS is a brand of Springer DE.

Springer DE is part of Springer Science+Business Media.

www.springer-vs.de 


\section{Acknowledgements}

Writing this book would not have been possible without the support of many people. I am very grateful to my supervisor Christoph Görg, for his advice and critical oversight during all phases of the project. I am also grateful to Peter Newell, for his hospitality in Norwich, and for raising important questions regarding the objectives of my work; to Neil Adger, for welcoming me at the University of East Anglia, and for vital advice and help in orienting my empirical research; to Christoph Scherrer and the participants of his doctoral colloquium in Kassel, for broadening my understanding of discourse theory and the challenges of methodology. The Helmholtz Centre for Environmental Research in Leipzig provided me with a scholarship that allowed me focusing on my research for three years.

In particular, I would like to thank the following people for supporting me in many ways while I was writing this book: Aaron Leopold, Benjamin Stephan, Chris Methmann and Delf Rothe, for contributing to the intellectual environment that helped my project to progress; Martin Bitter and Jakob Horst, for discussing my ideas and questions many times, and for all the talk during coffee breaks; and, of course, Anne Binder and Jenny Jungehülsing, for always being there and cheering me up.

I am most indebted to my family, for constantly supporting me in pursuing my goals, and in particular to you, who in so many ways made me who I am: I would have wanted you to read this book! 


\section{Table of contents}

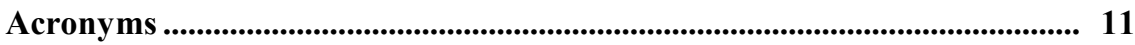



1.1 Towards a new rationality in climate governance …........................... 13

1.1.1 Climate change as economic challenge ....................................... 14

1.1.2 The emergence of the climate investment discourse................... 15

1.1.3 And a return of the state............................................................ 17

1.2 The research project ........................................................................ 18

1.2.1 State of research: Stern and investment for climate protection... 20

1.2.2 A discourse perspective on the economics of climate change..... 22

1.2.3 Governmentality and climate change....................................... 26

1.2.4 Operationalisation, research strategy, and structure of the book 30

2 Theory: Power/Knowledge..................................................................... 33

2.1 Epistemology: Archaeology, Genealogy, Power.................................. 35

2.1.1 Archaeology of discourse ......................................................... 35

2.1.2 Genealogy, the question of power, and power-knowledge.......... 39

2.1.3 Government as power ................................................................ 44

2.2 The analytics of government and the role of the state ........................ 47

2.2.1 The state as effect of governmental rationality ........................... 48

2.2.2 Emergence and change of governmental rationalities ................ 52

2.2.3 Analysing discourse from (governmental) practices................... 56

2.3 Operationalisation ....................................................................... 61

2.3.1 Ontology, epistemology, methodology ....................................... 61

2.3.2 Research process and methods .................................................. 68 
3 Economic rationality in climate governance

3.1 The old rationality of governing climate change ................................. 76

3.1.1 A short history of carbon markets in climate governance ........... 76

3.1.2 Neoliberal rationality: Markets and flexibility ……………............. 79

3.2 Stern and the economics of climate change: changing perspectives... 84

3.2.1 Reframing climate change as an economic problem................... 84

3.2.2 Turning climate governance into an economic challenge ........... 90

3.2.3 The limits to economic rationalisation.......................................... 96

3.3 After Stern: towards a new rationality in climate governance .......... 100

4 Making investments an object of government ....................................... 105

4.1 Climate finance: supporting north-south investment flows................ 106

4.1.1 The early days of adaptation and finance .................................... 106

4.1.2 The new importance of climate finance........................................ 110

4.1.3 Climate finance as investment ....................................................... 118

4.2 Low-carbon strategies: Investing in economic future ........................ 127

4.2.1 A Green New Deal ................................................................ 128

4.2.2 The low-carbon growth narrative .................................................. 133

4.2.3 Low-carbon growth and development: country perspectives..... 137

4.2.4 Going low-carbon: towards economic rationality ....................... 147

4.3 The finance sector in climate change governance.............................. 149

4.3.1 Renewable energy governance: Bringing in the finance sector . 150

4.3.2 Understanding investor behaviour ............................................ 157

4.4 Investment for climate protection: visibilities and invisibilities ........ 162

5 Governing investment for climate protection ............................................ 165

5.1 Public Finance Mechanisms: incentivising private investment.......... 166

5.1.1 Investment for low-carbon growth: UK GIB ............................ 166

5.1.2 PFMs for clean investment in developing countries ................... 169

5.1.3 The other side of PFMs: raising public finance.......................... 178

5.2 Investment and the carbon market....................................................... 182

5.2.1 Sensing investment opportunities.............................................. 182 
5.2.2 Governing carbon market investment ........................................ 184

5.2.3 Enhancing the effectiveness of carbon trading........................... 190

5.3 Investment and forest protection: the REDD mechanism.................. 193

5.3.1 From Kyoto to Copenhagen: forest in the climate regime.......... 193

5.3.2 The REDD mechanism: rising support for forest protection...... 196

5.3.3 Governing investment for forest protection.................................. 200

5.4 The investment dispositif in climate governance .............................. 204

6 Markets, investment and the state ........................................................ 207

6.1 From reducing emissions to building low-carbon economies ............ 208

6.1.1 A new political economy of climate change................................. 208

6.1.2 From markets to finance in climate governance .......................... 212

6.2 Climate protection in a financialised world economy......................... 216

6.2.1 Governing investment, creating markets ..................................... 217

6.2.2 The need for contesting the power of financial markets............. 223

6.3 The competition state in climate governance ................................... 227

6.3.1 Going low-carbon as new competitiveness ............................... 227

6.3.2 An emancipatory approach to the low-carbon transformation ... 231

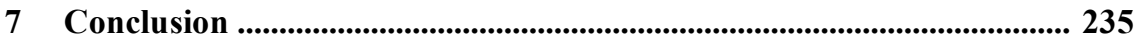

7.1 A look back: What has been achieved, and what remains to do ........ 236

7.1.1 Theoretical and methodological challenges................................ 237

7.1.2 Discourse theory analysis and the question of critique............... 241

7.2 A look forward: What future for international climate politics?....... 244

7.2.1 What is wrong with a global top-down approach....................... 245

7.2.2 But what still might be right about international cooperation.... 248 


\section{Acronyms}

$\begin{array}{ll}\text { AF/AFB } & \text { Adaptation Fund/Adaptation Fund Board } \\ \text { AGF } & \text { UNFCC Secretary General High-Level Advisory Group on } \\ & \text { Climate Finance } \\ \text { AR4 } & \text { Assessment Report 4 of the IPCC } \\ \text { CDM } & \text { Clean Development Mechanism } \\ \text { CIFs } & \text { Climate Investment Funds } \\ \text { COP } & \text { Conference of the Parties (to the UNFCCC) } \\ \text { CTF } & \text { Clean Technology Fund } \\ \text { EU ETS } & \text { European Union Emissions Trading Scheme } \\ \text { GDP } & \text { Gross Domestic Product } \\ \text { GEF } & \text { Global Environment Facility } \\ \text { GGGACC } & \text { Global Greenhouse Gas Abatement Cost Curve } \\ \text { GHG } & \text { Green House Gases } \\ \text { GIB } & \text { Green Investment Bank } \\ \text { GND } & \text { Green New Deal } \\ \text { GNDG } & \text { Green New Deal Group } \\ \text { IADB } & \text { Inter-American Development Bank } \\ \text { IPCC } & \text { Intergovernmental Panel on Climate Change } \\ \text { LDCF } & \text { Least Developed Countries Fund } \\ \text { MDB } & \text { Multilateral Development Bank } \\ \text { MIGA } & \text { Multilateral Investment Guarantee Agency } \\ \text { MRV } & \text { Monitoring, Reporting, Verification } \\ \text { NAMAs } & \text { Nationally Appropriate Mitigation Actions } \\ \text { NGO } & \text { Non-Governmental Organisation } \\ \text { PFM } & \text { Public Finance Mechanism } \\ \text { REDD } & \text { Reducing Emissions from Deforestation and Degradation } \\ \text { SCCF } & \text { Special Climate Change Fund } \\ \text { SCF } & \text { Strategic Climate Fund } \\ \text { UNEP } & \text { United Nations Environment Programme } \\ \text { UNEP FI } & \text { UNEP Finance Initiative/Sustainable Energy Finance Initiative } \\ \text { UNFCCC } & \text { United Nations Framework Convention on Climate Change } \\ \text { WBCSD } & \text { World Business Council on Sustainable Development } \\ \text { WEF } & \text { World Economic Forum } \\ & \end{array}$

